\title{
Germany's Vocational Training Act: its function as an instrument of quality control within a tradition-based vocational training system
}

\author{
THOMAS DEISSINGER
}

ABSTRACT This article looks at the link between the established tradition of a nation's vocational training system and the specific pattern of state or government involvement in the process of skill formation. It is based on the perception of the different features of the German and the English approach towards the qualification problem. In the Federal Republic of Germany, the Vocational Training Act submits vocational training to a certain amount of quality control. This control, however, is merely injected into existing patterns and procedures and therefore the state's function is only partly one of defining standards and conditions. It builds on specific traditions which allow a variety of agents and institutions to become involved in the process of qualifying young people for skilled occupations.

\section{LOOKING AT VOCATIONAL TRAINING IN COMPARATIVE EDUCATION: THE IMPORTANCE OF THE LEGAL FACTOR}

The pattern of vocational training which developed with the rise of the guilds in the Middle Ages exists both in Germany and in England. Taking up an apprenticeship meant to serve a period of time with a master who was entitled and obliged to host, feed and educate the apprentice. The educative function of apprenticeship training extended to imparting those social skills which complied with what was considered the apprentice's calling in a highly stratified society. This apprenticeship model of vocational training began to erode in pre-industrial times when the decline of the guilds and the emergence of free work re-defined the social and economic terms for vocational training [1]. In England, it was never efficiently protected against the emerging spirit of capitalism by either Crown or Parliament, although the Elizabethan Law of 1563, which had sanctioned medieval apprenticeship, was not repealed until the year 1814 (Derry, 1931/32). The ensuing period of laissez-faire lasted up to 1964 when the Industrial Training Act, for the first time, broke with the paradigm of state non-interference (Page, 1967). Today, however, vocational training in England mainly takes place in a 'free market context' where state participation, apart from financial functions, is weak and private responsibility for organising and defining training predominates. The heterogeneous ways of integrating young people into the labour market mostly follow routes not linked or related to classical apprenticeship which, as an institution, has suffered a sharp decline in the recent past [2]. Although the recent training initiative of the UK government, called 'modern apprenticeship', aims to 'pick out the best' of traditional apprenticeships (normally based on time-serving) while linking them to 


\section{8}

competence-based qualifications (Hill, 1995), the question remains whether this innovation indicates that restoring apprenticeship as the general pattern of vocational training might again be the major objective of English training policy. Neither has the role of the state changed substantially. On a large scale it is still that of non-interference-apart from institutional, administrative and financial functions which yet underline that vocational training should remain the duty of employers in the first place [3].

This article looks at the link between the traditional pattern of apprenticeship and state regulation which was severed in England, but can still be observed in the 'Dual System' of Germany. The following arguments are based on the assumption that the concurrence of these two variables in the qualification process forms a significant determinant of quality control. While in Germany the state has emerged as a forceful agent in promoting vocational training, in England it has traditionally been held that 'preparation for production was best given on the job rather than in formal education' (Child et al., 1983, p. 73). Peter Raggatt, as an English observer, underlines the difference between the two countries by stating that, in England, legislation has always been viewed as 'restricting rights' whereas in Germany 'the law is regarded as guaranteeing rights' (Raggatt, 1988, p. 176). Indeed, the law which governs the 'Dual System'-by clearly setting up roles and responsibilities for the various participantsprovides 'continuity with the past', but at the same time functions 'as a primary source of quality control' (ibid.). This implies that the German system of vocational training, though not being state-controlled in a comprehensive sense, certainly contains elements of both regulation and-with respect to the vocational school-of compulsion which the English 'mind of training' would not accept or even allow [4]. When it comes to talking about the legal factor in the process of skill formation in Germany the Vocational Training Act, passed in 1969, comes into focus as the major instrument to inject quality control into the 'Dual System'. Its global function may be seen in integrating the traditional concept of skilled apprenticeship with the modern idea of state responsibility.

\section{THE HISTORICAL ROOTS OF THE MODERN SYSTEM OF INITIAL TRAIN- ING IN GERMANY}

In-company Training

The genesis of the modern vocational training system called the 'Dual System' [5] is determined by the emergence of substantial activities on the part of the state to promote the ancient craft system. This happened against the background of a degenerating guild system which, from the middle of the 19 th century, also became badly affected by the Industrial Revolution. Long before the 'take-off' in the process of industrialisation, however, guild privileges - seen as obstacles in the process of re-formation of state and society-had been removed in the Prussian territories (Stratmann, 1982, p. $178 \mathrm{ff}$.). In 1845, a Trade Act (Stratmann \& Schlüter, 1982, pp. 122 ff.), though not repealing free enterprise in general, re-imposed restrictions on free craftsmanship by confining the taking of apprentices to masters within a guild. The Trade Act of 1849 , following this line by stressing the distinction between workshops and industrial premises, restricted the right to take apprentices in craft occupations to examined journeymen. The definition of apprentice, however, was extended to everybody who entered an employment with a master to learn a trade notwithstanding whether he paid a premium or became a wage-earner (Stratmann \& Pätzold, 1984, pp. 117-119). Inevitably, in 1869, 
the Gewerbeordnung (Trade Act) of the North German Federation (Schlüter \& Stratmann, 1985 , p. 145) unequivocally and universally re-affirmed freedom of trade. With respect to apprenticeship it simply prescribed that the apprentice had to be subjected to an employer obliged to instruct and employ him. Hence the Act clearly failed to define what was to raise the status of the apprentice above that of the juvenile worker (Stratmann, 1991, p. 372). The guilds eventually were deprived of their role as agents entrusted with the organisation of vocational training which had been confirmed by the preceding trade acts (Kiesewetter, 1989, p. 55 ff.).

In the 1880 s and 1890 s the National Conservatives, the Catholic Centre Party and some of the National Liberal Party succeeded in attaining crucial amendments to trade legislation based on anti-liberal economic thinking (Winkler, 1976, p. $1 \mathrm{ff}$.). The most significant result of this policy was the Handwerkerschutzgesetz (Act to Protect the Crafts) passed in 1897 (Schlüter \& Stratmann, 1985, p. 210) which provided for craft chambers (Handwerkskammern) as institutions of public law and for the so-called compulsory guild option (fakultative Zwangsinnung). Membership of a guild became mandatory if the majority of craftsmen of a branch in a given local community had decided to found such an institution. The regional craft chambers as well as the local guilds were installed as major agents of training which, in particular, meant that they were authorised to hold examinations for journeymen and masters. The notion of the skilled craftsman thus became rooted within a framework of self-government which was based on economic law. The 1897 Act also confined the technical qualification required for the training of apprentices to skilled journeymen of at least 24 years of age who had either served a three-year apprenticeship or pursued their trades for at least five years as independent artisans. Indentures became general practice in the craft sector as well as the three-year training period. In 1908, the right to train apprentices was again restricted to craft masters. In 1953, the Handwerksordnung (Craft Regulation Act) made comprehensive provisions for in-company training in craft premises, including the taking and instruction of apprentices, which remained linked to the master's certificate. It drew up a list of 111 trades defined as craft occupations (Benner, 1987, p. 281). The ancient model of initial training thus was implanted into German post-war society.

The prototype of apprenticeship within the 'Dual System' had originated in the craft sector. After the First World War, however, industrial employers' organisations began to work out occupational profiles. Their attempt to establish a mode of training apart from the craft sector was manifestly more closely linked to the idea of systematised training schemes than to vocational traditions (Schütte, 1992, p. 79). From the mid-1920s, the chambers of industry and commerce embarked on holding examinations for industrial workers, which until then had been the exclusive right of the craft chambers (Muth, 1985). By 1937, some 100 trades had been based on skill profiles which underpinned the examination mode (Benner, 1987, p. 273). Despite the more modern character of industrial training it also stuck to the corporatist framework as well as to the occupational orientation of the training process, which had been a pivotal trait of traditional apprenticeship. Yet the role of the state remained that of a sanctioning agent. The dominant feature of in-company training in Germany up to 1969, when the Vocational Training Act came into operation, can be seen in the sole responsibility of firms and chambers-clearly a tribute to classical apprenticeship as it had been revitalised in the late 19th century. 


\section{The Part-time Vocational School}

In the late 19th century, compulsory attendance of the part-time continuation school gradually emerged as the second pillar of the 'Dual System'. Fortbildungsschulen (continuation schools) had been made obligatory as early as 1869 when the Gewerbeordnung had provided for compulsion but had left it to individual communities to pass by-laws for this purpose. There were also the school laws of the German Länder (states) which contained divergent regulations concerning continuing education. Although the Craft Act of 1897 also demanded that the apprentice had to be released from work to attend a continuation school and that his master had to ensure he did so, the character of the German continuation school system remained rather heterogeneous, primarily because of attendance regulations diverging regionally. Furthermore, its curriculum could hardly be described as paying attention to the occupations of those who went there. As a matter of fact, most continuation schools were concerned with elementary education rather than the teaching of vocational skills (Blankertz, 1982, p. 205).

It was the work of Georg Kerschensteiner (1854-1932), the educational thinker and school reformer (Müllges, 1967, p. 11) which established continuation schools following a specific pattern of institutional and didactic principles, although he was not the 'inventor' of such schools (Abel, 1963). His aspiration consisted in founding obligatory continuation schools linked to specific occupations, which he called $o b-$ ligatorische fachliche Fortbildungsschulen. These schools had the purpose of replacing general continuation schools. Kerschensteiner's concern for school-leavers was based on the conviction that 'education for the ordinary man and woman must be woven into the practical work of life' (Higginson, 1990, p. 248). Kerschensteiner's continuation school, which later on was called Berufsschule (vocational school), linked vocational training to the school system by no longer denying the educative value of practical work (Simons 1966, pp. 48-52). Its function was to complement workshop training by aiming at Menschenbildung (education of the individual) and, at the same time, was based on a concept which saw the individual as essentially a social being, both with respect to his occupation and to his citizenship within the community. The workshop with the Meister was considered as important a 'learning venue' as the vocational school which, besides providing useful knowledge and a sound moral attitude, should also make provision for practical training. As to its basic principles and its function within the vocational training system, the modern vocational school in Germany still follows the principles underlying Kerschensteiner's concept, although there have been modern adaptations of the curriculum and new methods of instruction (Pätzold, 1992; Reinisch, 1995).

On a national scale, compulsory attendance at the Berufsschule for 14-year-olds did not materialise until 1938. The Compulsory School Attendance Act (Reichsschulpflichtegesetz) required apprentices and juvenile employees to be released from work and subjected employers to fines in the case of non-observance. The part-time vocational school had to be attended for a period of three years (or two years in the case of agricultural occupations). The Ministry of Science and People's Education, in 1940, fixed its share of vocational training to six to eight hours a week (Kümmel, 1980 , pp. 278-280). The stipulations of the 1938 Act which provided for compulsory part-time attendance were included in the school acts of the Länder of the Federal Republic after 1949. 
THE FRAMEWORK OF A SEMI-PRIVATE APPROACH TO WORKFORCE RECRUITMENT: THE 'DUAL SYSTEM'

\section{Structural Features of the 'Dual System'}

Raggatt calls the 'Dual System' the 'centrepiece of vocational education and training in the Federal Republic' (Raggatt, 1988, p. 166). This is certainly true as its quantitative importance dwarfs the vocationally orientated schools that do not provide training for a skilled occupation as well as the school-based training schemes of the Länder (Zabeck, 1985). It represents an institutional and organisational framework based on legal provisions and training arrangements which are determined by two 'learning venues' (see Figure 1): the company or master providing the apprenticeship and the part-time vocational school which assumes the part of instructing the apprentice in addition to his practical training (Deutscher Ausschuss, 1966, p. 418). There is also a shared responsibility for the funding of the qualification process between companies and Länder governments as well as a dualism of legal responsibilities (Raggatt, 1988, p. 166). As a whole, the system is determined by private, semi-private and public interests and responsibilities including the trade unions and, in particular, the chambers (of industry and commerce, the crafts and the professions). As in England, vocational training is based on the notion that, in the first place, it ought to be the concern of companies and not part of the government's duties. However, there are striking differences between the two countries. First, in Germany, the chambers execute a crucial part of the functions and mechanisms which make vocational training 'occupation-led' rather than 'company-based'. Secondly, the state's role is thoroughly defined and extends to both 'learning venues'. Whereas in England, for example, on-the-job-training is merely complemented by off-the-job-training on a voluntary basis, in Germany it is mandatory. The State Education Acts (Landesschulgesetze) provide the legal framework and make sure that school-leavers who have found employment or entered a course of training are kept within the education system. Everybody under the age of 18 not in higher or further education is compelled to attend the local part-time vocational school (Berufsschule) on a sandwich or day-release basis. In fact, everybody commencing an apprenticeship is required to stay on at school until the end of the training period which normally stretches over three years [6]. For each 'recognised skilled occupation' the Länder of the Federal Republic work out didactic patterns laid down in syllabuses (Rahmenlehrpläne) for vocational and general subjects taught at part-time vocational schools (Greinert, 1994; Münch, 1994).

An apprenticeship in the 'Dual System' gives young people the opportunity to obtain qualifications which open the path to various employments within an occupationally structured labour market (Beck et al., 1980; Maurice et al., 1979). The system is almost universal since it recruits about three-quarters of the 16-to-19-year-olds and thus contributes to holding the number of unskilled employees down (Büchtemann et al., 1993, p. 510; Greinert, 1994, p. 116). In 1990, 59\% of leavers from ordinary secondary schools (Hauptschulen), $57 \%$ of middle school (Realschule) leavers (as against $47 \%$ in 1970 ) and $15 \%$ (as against $4 \%$ in 1970) of 'A-level holders' from the grammar schools (Gymnasien) entered an apprenticeship in the 'Dual System' (Schober \& Tessaring, 1993, p. 8). Unlike England or France, where they form a marginal sector within the vocational training systems, apprenticeships exist in all branches of the German economy including the professions and parts of the civil service. In 1994, 567,840 young people took up an apprenticeship. For the training year starting 1 October 1995, the latest figure reported amounts to 572,774 apprenticeship contracts. Currently, 


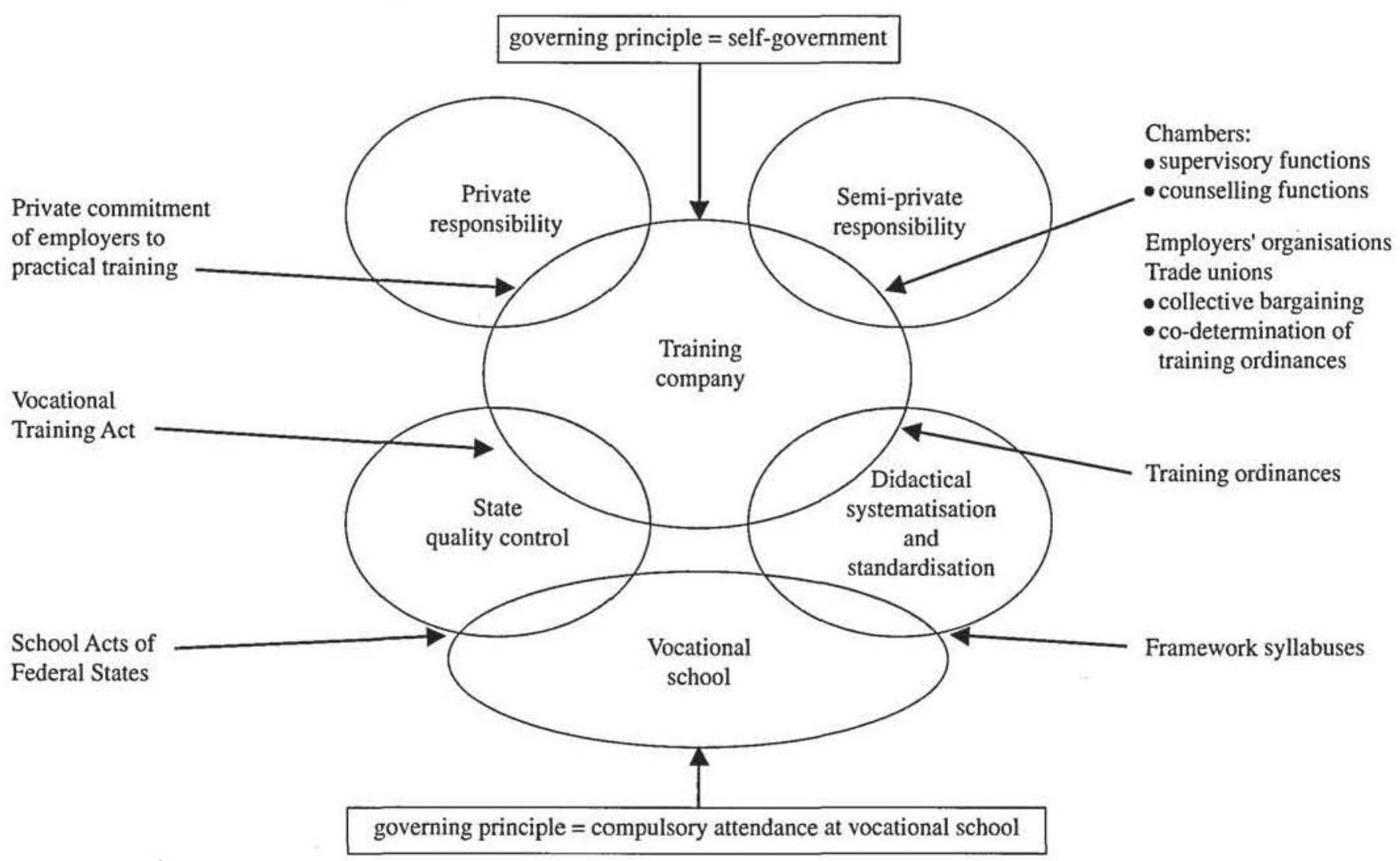

FIG. 1. Structural features of the 'Dual System' of vocational training in the Federal Republic of Germany. 
approximately 1.68 million young people $-40 \%$ female-are learning their trades through the 'Dual System'. In 1995, 45.9\% had contracted with an industrial or commercial firm while $37.3 \%$ had entered a traditional craft apprenticeship. The strong contribution of small businesses to the supply of training opportunities within the 'Dual System' is clearly underlined by the fact that the car mechanic tops all other occupations with its share of $8.4 \%$ of all male apprentices [7].

\section{The 'Dual System' under Scrutiny}

Recently, the 'Dual System' has become the object of criticism and scepticism about whether, as a tradition-based training system, it will be able to master the challenges of the late 20th century in the way it did in the past. Although the number of 'open' training places still amounts to 44,200 (September 1995) there are structural and regional frictions on the training market as well as developments which put the 'Dual System' under pressure from outside. Yet, in 1995, firms as a whole provided 617,000 trading places a rise of $0.8 \%$ from 1994. In the east of Germany there has been an upswing which took new apprenticeships up $4.1 \%$ to 122,646 [8]. The fact that in the new federal states the number of in-company training opportunities has risen seems quite remarkable considering the structural problems of the economy there (Degen $e t$ al., 1995). On the other hand, unemployment is currently Germany's major social and economic problem which certainly puts strain on the training system [9]. At 'threshold one'-between school and vocational training (Zabeck, 1979)-the 'Dual System' still performs quite satisfactorily in its 'absorbing function', although all social groupsstarting with employers - will have to strengthen their efforts to provide training places for school leavers as the demand is expected to rise between $1 \%$ and $2 \%$ p.a. within the next 10 to 15 years (Kümmerlein, 1996). Although the correspondence between the training system and the employment sector is still strongly determined by a professional or vocational link, career opportunities based on skilled training are more likely to become exposed to labour market restraints these days (Timmermann, 1994, p. 81). A survey carried out by the Federal Institute for Vocational Training reveals that while in 1991 only $12 \%$ of apprentices in the metal sector and $10 \%$ in the electrical branch were not taken over by their training firms after completion of apprenticeship this portion rose to $28 \%$ and $27 \%$ respectively in 1993 . The share of those affected by unemployment directly after completion of training naturally differs between occupations and sectors of the economy: $15 \%$ of metal trade apprentices contained in the panel suffered this fate in 1993, but only $4 \%$ of trainees in the commercial and services sector became unemployed (Schöngen et al., 1994, pp. 95-101).

As job opportunities for freshly trained journeymen or industrial workers have worsened in the wake of the present economic crisis the allocating function of the 'Dual System' indeed seems at risk (Schober, 1994, p. 20). Yet there is no convincing proof that this function, which helped to prevent youth unemployment in the past more successfully than was the case in other European countries (Clement, 1985; Casey, 1986), could be at the core of this 'unsuccessful story' (as no training system in the world can create jobs). This argument is supported by the problems that more market-steered vocational training systems with neither a dual learning arrangement nor a vocational or occupational basis of the qualification process, such as England or the United States, have faced up to the present day, while the mismatch between 
vocational education and the world of work in school-based and state-controlled systems, such as France, is also well known. It may be asserted that the so-called crisis of the 'Dual System' appears first and foremost to be conditioned by the labour market and other external factors rather than by severe qualitative problems or structural inflexibility.

With regard to the external forces exerting influence on the 'Dual System' the current debate centres around two aspects that are not directly linked to the economic framework, and thus the labour market in particular, which co-determine the training system and its ability to open up paths to employment: Greinert holds that the 'crisis of the dual system is [...] mainly a dilemma of adapting to social rather than technological and economic changes' (Greinert, 1994, p. 118). The 'real danger' threatening the existence of the 'Dual System' may be seen in the phenomenon that education and career aspirations of young people and their parents have markedly shifted towards the academic sector which is considered to be the 'golden path' to higher social status and income (Lutz, 1991; Schober \& Tessaring, 1993). This 'meritocratic mind' in terms of career expectations is accompanied by a tendency with companies to prefer graduates from the Universität or Fachhochschule for jobs that for a long time produced career opportunities for skilled workers or artisans, especially for those who had qualified to become masters or technicians. It appears as a rejection from companies of a policy of recruiting young employees through a company-based apprenticeship and could jeopardise the 'Dual System' and its traditional clientele alike as it dries up career trajectories outside the higher education system (Zabeck, 1995, p. 98). Cost-cutting measures in the wake of the current economic crisis could well aggravate this trend.

Efforts that have been undertaken in the last ten to 15 years to modernise the 'Dual System' could help to paint a more optimistic picture of Germany's vocational training system than is suggested by those dominating the public debate. The major innovation which was implemented may be seen in the re-definition of occupational profiles (which in general will be discussed later on), above all in the metal trade (1987), but also in crucial commercial occupations (1991). These newly regulated occupations have become more exacting, they pay tribute to data processing as a significant aspect of a modern employee's competence and open up as well as require new ways of teaching techniques and training arrangements (Benner, 1994). Nevertheless, some critics do not shy away from bringing discredit onto the German 'Dual System' by maintaining its obsolescence in the face of an increasingly changing economic and social environment (e.g. Geissler, 1991). By rejecting judgments of this kind it is not asserted that the German vocational training system is perfect and should be shielded from scrutiny or criticism. However, as to its allocating function-with respect to both thresholds to be crossed on the path from school to employment-there does not seem to exist a realistic alternative to an approach which unifies the public and the private sphere in solving one of the most challenging problems facing the industrialised world. Indeed, on the international platform the 'Dual System' has always enjoyed admiration and confidence as a comparatively efficient training concept, both in Europe and in the developing world (Münch, 1992). Though being a market approach with apprenticeship at its core (which guarantees the basic commitment to training from employers) one of its striking features is that it avails itself of structural qualities due to the existence of instruments of quality control. For many observers it deserves particular attention as a 'training system in which clearly defined competence profiles can be acquired on a very reliable basis' (Lutz, 1994, p. 27). The following section tries to show that the instruments which have been designed to serve this goal do not submit the 'Dual System' to an 
overall state-responsibility as they partly recur to traditional features of vocational training.

\section{THE VOCATIONAL TRAINING ACT}

\section{Purpose and Character of the Act}

There had been attempts since the 1920 s to place in-company training under the auspices of the state. In 1927, a bill was drafted for a Vocational Training Act which was to pay tribute to the vocational school as a 'learning venue' as well as to the growing influence of the trade unions. It never became law because of unfavourable external circumstances due to the economic depression. Another bill of 1942 did not materialise against the background of the Second World War. In the 1950s and 1960s, trade unions and Social Democrats joined in a common plea for new legislative action to counterbalance the predominance of the chambers and guilds in the process of skill formation which was mainly based on the existing trade law. However, exposing in-company training to state scrutiny and moulding it into a legal framework for a long time seemed inconceivable as the training tradition stemming from the 19th century, which was supported by educational thinking-the so-called Kulturpädagogik (Stratmann, 1979, p. 304 ff.; Stratmann \& Schlösser, 1990, p. 53 ff.)-proved strong and firms were not eager to give up their dominant part in the training process. The 1969 Vocational Training Act thus may be viewed as the final stage of a debate determined by diverging opinions among political parties and social partners about the degree to which the 'Dual System' as a whole should be submitted to state influence.

In 1966, a training bill, brought to the Bundestag by the Social Democratic opposition for consideration was followed by one on behalf of the government. The latter formed the basis of the Vocational Training Act which, after a course of comprehensive consultations between the parties, was finally passed on 14 August 1969, and came into operation on 1 September 1969 (Münch, 1969). As a compromise, the Act did not install a new training system including the vocational school, but mainly 'consolidated much previous practice under one Act' (Raggatt, 1988, p. 175). Yet there can be no doubt that, at the time of its passing, the Vocational Training Act represented the first comprehensive set of legal regulations for in-company initial training as well as continuing training and retraining (Section 1) [10]:

(1) For the purposes of this Act the expression 'vocational training' means initial training, further training and retraining. (2) The object of initial training shall be to provide, through a systematic training programme, a broadly conceived basic preparation for an occupation and the necessary technical abilities and knowledge to engage in a skilled form of occupational activity. Initial training shall also enable a trainee to acquire the necessary occupational experience. (3) Further training shall be designed to enable a trainee to maintain or extend his vocational knowledge and abilities, adapt himself to technical developments or obtain promotion in his chosen occupation. (4) Retraining shall be designed to qualify a trainee for another form of occupational activity.

Like the 1953 Craft Regulation Act, the Vocational Training Act is a Federal Act and therefore only governs training at the workplace, which means that it does not interfere with the Länder responsibility for vocational education in schools [11]. This is made 
clear by Sections $1 \mathrm{~V}$ and 2 I where potential 'training venues' are listed although the vocational schools are excluded from the scope of the Vocational Training Act as they are seen as 'covered by the laws of the various Länder governing education establishments'. By referring to the constitutional aspect it also becomes evident that the Vocational Training Act is essentially a specified labour law since its central object is the indenture between the apprentice and the training company (Section 3). However, there are elements which make it difficult to ignore that vocational training is also rated as an educational process. This educational bias underpins the definition of training as crucially an apprenticeship following the traditional pattern of skill formation while at the same time giving the state a controlling stake.

The character of the Vocational Training Act may be summarised by pointing out two central features:

- Firstly, the Act places vocational training in the hands of firms and chambers and thus emphasises the principle of self-government (Zabeck, 1975) while at the same time defining the framework where it has to take place. The fact that parts of the Act do not apply to crafts does not imply the lack of a traditional basis. The crucial sections concerning training in both the Vocational Training Act and the 1953 Craft Regulation Act are compatible or at least highly similar to each other. The Act takes account of the traditional features of guild apprenticeship while at the same time submitting in-company training to homogeneous, supervisable and examinable standards. The 'competent authorities' (zuständige Stellen) are in charge of monitoring in-company training and of holding exams for journeymen, skilled industrial workers, commercial clerks and masters [12]. They represent an essential element of what may be called the sphere of public or semi-private responsibility within the 'Dual System' (see Figure 1).

- Secondly, the Act pays tribute to the 'Dual System' as a whole, although the term itself is not mentioned and neither are there regulations concerning the vocational school directly. Nevertheless, the Act contains stipulations which confirm the existence of the other 'training venue' and thus allude to a common responsibility of both firm and school [13]. At the same time, as already mentioned, the Vocational Training Act clearly restricts its scope of application, as part of the federal law, to in-company training by mentioning that the Länder possess the responsibility for part-time vocational education. This confinement is based on discrete legislative functions between Land and Bund which the Basic Law (Grundgesetz) of 1949 has laid down, such as the school law and the law of labour.

The Vocational Training Act covers both the private and the public sphere of vocational training. Whereas in the private sphere apprenticeship appears as a specified employment (Part II, Sections 3 to 19), the public sphere, extending the scope of the Act to the 'organisation of vocational training' (Part III, Sections 20 to 49), makes it an issue of general interest and social importance. The contribution of the Vocational Training Act to systematising and standardising the course of training can be seen in three areas where legislation protects vocational training from market forces. The first one touches the training contract or indenture which makes the Vocational Training Act 'the most comprehensive and detailed regulatory system for apprenticeship training in the Western world' (Raggatt, 1988, p. 175). The second aspect brings into focus the degree to which skill requirements of trainers have become formalised. The third one refers to the question how an apprentice in the 'Dual System' has to be instructed and 
what knowledge and skills have to be provided to prepare a young person efficiently for a skilled occupation.

\section{The Character of the Training Contract}

A substantial part of the Vocational Training Act's stipulations concern the training contract or apprenticeship indenture (Sections 6 to 19). They cover several of the most significant aspects of the qualification process, such as the objective, the structure and duration of the training period, the time devoted to training every day, the apprentice's pay (subject to collective bargaining) as well as his or her rights and duties. Apprenticeship indentures constitute the special legal status of the trainee. The essentials concerning the training relationship between the training company (called $\operatorname{der}$ Ausbildende) and the trainee or apprentice (called der Auszubildende) must be laid down in writing (Greinert, 1994, p. 86 ff.). The contract obliges the training employer, above all, to ensure that the necessary abilities and knowledge shall be imparted to the apprentice. This means that training has to be purposeful and organised in accordance with the formal training objective consisting in the passing of the examination before the chamber. The educational content of the indenture may be measured by the emphasis the Act places on the requirement of skilled training personnel as well as by the fact that there is an obligation of the training firm to see 'that the trainee is encouraged to develop his personality and that he is protected from physical or moral danger' (Section $6 \mathrm{I})$. Moreover, the apprentice must not be treated as an ordinary employee: he 'shall only be entrusted with such jobs as are related to the purpose of his training and are commensurate with his powers' (Section 6 II). Firms' duties also include the releasing of trainees from work both for the attendance at the vocational school and for the sitting of examinations (Section 7). On the other hand, the apprentice, too, has to comply with certain requirements concerning his behaviour and, in particular, his duty to attend the vocational school (Section 9).

Training contracts must be registered with the regional chamber (Section 31). The 'competent authorities' have an overall responsibility for the contractors' obedience to the agreement. Thus, companies are bound to a legal system which prevents them from training young people simply in accordance with their economic or technological needs. The Berichtsheft (log book), which the apprentice has to keep (Section $6 \mathrm{I}$ ), must be regularly checked and signed by the person-a trainer or master-who is in charge of instructing and monitoring the apprentice in the training firm. Accusations of weakness and abuse of in-company training can be brought before the chamber by either side. As to the overall legal status of the apprentice the Vocational Training Act forms but a part of a range of Acts which were passed as specified labour law, such as the Industrial Constitution Act (Betriebsverfassungsgesetz) of 1972, the Youth Employment Protection Act (Fugendarbeitsschutzgesetz) of 1960, amended in 1976, and, of course, the Craft Regulation Act (Handwerksordnung) of 1953, amended in 1965 and 1990. Each of them contains provisions with respect to the employment aspect of apprenticeship (Greinert, 1994 , p. 85 ff.).

\section{The Regulation of Trainers' Qualification}

The Vocational Training Act not only stipulates the rights and duties of trainees and training companies, but also prescribes the personal and technical skills of training 
personnel. For this purpose, the Act distinguishes between the trainer and the person or firm taking on apprentices (Section 20). The 'personal aptitude' (persönliche Eignung) means that a person must not have contravened the Vocational Training Act and must not be prohibited from employing young people. These preconditions are basically deemed sufficient for hiring an apprentice. However, a person engaging in apprenticeships also has to prove they have the competence (fachliche Eignung) for instructing the apprentice at the training site, unless there is a training officer with the necessary personal and technical qualifications to provide the training (Section $20 \mathrm{IV}$ ). Therefore the trainer himself, besides his 'personal aptitude', must have technical, i.e. occupational and pedagogical abilities and knowledge, which means that he has to be an expert in his occupation (Section 76) and that he has to have acquired educational and psychological skills including the application of appropriate teaching and instruction methods. In 1972, a trainer's qualification ordinance was decreed by the Federal Government. This is called the Ausbildereignungsverordnung (AEVO) and outlines the curriculum for trainers' courses normally offered by the 'competent authorities' (Weber, 1985, pp. 60-64). It is based on Section 21 of the Vocational Training Act.

The right to provide training clearly follows a historical pattern reaching back to the time when the 'Dual System' was formed: from 1897 on (Act to Protect the Crafts), only skilled journeymen above 24 years of age were entitled to train apprentices (Schlüter \& Stratmann, 1985, p. 225 ff.). With the Trade Act of 1908, a craftsman had to be a master if he intended to train young people. In 1953, the Craft Regulation Act confirmed that training in craft occupations required the master's qualification and a minimum age of 24 years. The Vocational Training Act pays tribute to the different historical developments in the craft sector and the branches of industry and commerce. Its stipulations have led to an adaptation and revision of already existing regulations such as the master's qualification. In 1972, the Allgemeine Meisterprïfungs-Verordnung (General Ordinance for the Master's Examination) adopted the AEVO as Part IV of the syllabus governing master training courses (Schwichtenberg, 1991, p. 27). The master undoubtedly still represents the major career aspiration of craftsmen and industrial workers, but training as an organisational and educational function has now been opened to a broader range of qualified people including university graduates and, above all, skilled workers, clerks or journeymen (Eyermann et al., 1973, p. $158 \mathrm{ff}$.). As an innovative measure the implementation of 'technical aptitude' in its more extensive meaning, including the occupational and the pedagogical aspect, has certainly contributed to the upgrading of training as an educational activity and not merely as a part of a company's personnel management (Arnold \& Hülshoff, 1981). The trainers' training courses organised by the Industrie- und Handelskammern (chambers of industry and commerce) have in due course become a permanent offer amongst the further education activities of the 'competent authorities'.

\section{The Regulation of the Didactic Dimension of Apprenticeship}

With the passing of the Vocational Training Act, which overcame the divergent developments in the craft and the industrial sector, the term Ausbildungsberuf replaced the terms Lehrberuf and Anlernberuf (Heilandt, 1980). Since then 256 recognised skilled occupations (staatlich anerkannte Ausbildungsberufe) have been based on new training ordinances (Ausbildungsordnungen). They apply to $97 \%$ of all apprentices. At present the number of existing skilled occupations amounts to 374 (Bundesministerium für 
Bildung, Wissenschaft, Forschung und Technologie, 1995, p. 67). Training ordinances set up the didactical pattern of the qualification process leading to an examination before a 'competent authority' (Benner, 1977). As the existence of a skilled occupation is dependent on a training ordinance its formal recognition requires government approval. The Vocational Training Act has laid the formal responsibility for training ordinances into the hands of the Federal Ministry of Education and Science (now the Federal Ministry of Education, Science, Research and Technology). However, in material terms, a training ordinance is never a sole product of the government's definition of the terms for initial training in companies. In fact, training ordinances are the result of comprehensive consultations among all social and political groups who have a substantial interest in vocational training, primarily employers' organisations and trade unions (see Figure 1). It is the job of the Federal Government, through the Federal Institute for Vocational Training (BiBB), to scientifically support and administratively coordinate these consultations, which normally stretch over a couple of years, and forge them into a clear didactic instrument (Greinert, 1994, p. 89). The procedure which leads to training ordinances claims to be reality-based and tries to take account of newly developing job requirements due to organisational and technological changes.

The present tendency with training ordinances is against too much specialisation. Between 1970 and 1990 the number of skilled occupations has decreased from around 600 to 378 . It is assumed that a broad basis of elementary vocational qualifications supports a maximum of flexibility and mobility between different workplaces and firms. This concept becomes evident in the new training schemes in the metal and electrical sector which were released in the late 1980s: specialisation only takes place after an initial training period of normally one year which is common to a whole range of inter-related occupations. Besides this recently implemented pattern the traditional structure of a 'recognised skilled occupation' is the Monoberuf, such as the banking clerk, with its homogeneous profile which does not imply the possibility of specialisation. In the $1970 \mathrm{~s}$, the third major pattern of the now existing concepts emerged as the so-called Stufenausbildung - a stage-based training scheme providing for different skill levels within a system of related occupations (Schelten, 1991, p. 85 ff.; see also Section 26 Vocational Training Act).

In Section 25 of the Act the contents of a training ordinance are specified. It must contain:

(1) the name of the skilled occupation;

(2) the duration of the training period, not normally more than three or less than two years;

(3) the skills to be provided by the company in the course of training;

(4) a specification of the syllabus to be followed for the purpose of imparting the relevant abilities and knowledge;

(5) and finally the examination standards.

The so-called Ausschliesslichkeitsgrundsatz (principle of exclusiveness) makes sure that training ordinances represent the only way which leads young people into skilled employment (Section 28):

(1) Training for a recognised trainee occupation shall be given only in accordance with the relevant training regulations. (2) Initial training in occupations other than recognised trainee occupations shall not be provided for 
young persons under 18 years of age unless it is intended to prepare them for

a subsequent course of instruction.

The idea behind this strict principle is based on the conviction that a systematised training course pins companies down to the skill range of an occupation which is marketable beyond the training company itself (Beck et al., 1980). A regulation of this kind differs most sharply from the philosophy underlying the English system of National Vocational Qualifications (NVQ) where the output aspect is given major attention by stating that it is the result and not the way which counts when it comes to defining qualification standards. However, this difference is more than a mere technical issue. The concept of 'recognised skilled occupations' represents a crucial part of the German tradition of in-company training although the first written qualification standards only reach back to the 1920 s. Besides demanding the systematic acquisition of marketable skills the dominant feature of this occupational concept (Berufsprinzip), deeply rooted in the tradition of ancient apprenticeship [14], may be seen in the implications for the trainees themselves: it severs the close connection between specific workplaces and the process of skill formation which tends to functionalise workplace skills and thus to restrict the mobility of employees.

\section{CONCLUSION: LEGALISM AND VOCATIONALISM - TWO PRINCIPLES OF QUALITY CONTROL IN GERMAN VOCATIONAL TRAINING}

It may be asserted that, both with respect to in-company training and post-compulsory part-time schooling, traditions going back to the late 19th century were transplanted into German post-war society. They underlie the pattern of vocational training which has become institutionalised as a 'Dual System'. Although the dualism of 'learning venues' and legal responsibilities may, at first glance, be the striking feature of this German system of vocational training (Greinert, 1994) its working principles as well as its efficiency appear to be much more determined by two parameters that govern the qualification process as a whole. On the one hand, there is no doubt that vocational training still follows a traditional pattern deeply enshrined in the ancient mode of apprenticeship which is still at the heart of the 'Dual System'. This vocationalism, as it may be called, not only means that training is workplace-led and predominantly practical by stressing the importance of work experience during the training period. It also means that the system works in accordance with skill requirements which are defined 'around the workplace' (Harney, 1985). The fact that this objective demands a didactic pattern embracing more than just what a specific job demands brings into focus the pedagogical implications and the social importance of vocational qualifications as well as the organisational and legal framework surrounding the two 'learning venues' (see Figure 1) which makes the 'Dual System' operate the way it does. This framework comprises both the administrative and organisational contribution of the competent authorities, based on the principle of self-government, and the involvement of the federal and state administration which helps to make occupational standards and conditions of skilled apprenticeship legally enforceable as well as marketable. Hence the second parameter injecting quality control into the 'Dual System' may be seen in the overall public interest in the qualification process which prevents it from being exposed to the forces of the market unrestrictedly. To label the 'Dual System' a 'bureaucratic horror by liberal standards' (Goodhart, 1994, p. 29) may sound exaggerated, but there certainly is a grain of truth in it as the legal aspect forms an essential part 
of this public responsibility. It becomes manifest in the 1969 Vocational Training Act which underlines the notion implanted in the German 'training culture' (Brown \& Evans, 1994) that vocational training should not be primarily rated as a contractual duty but as an educational process.

\section{NOTES}

[1] For a detailed depiction see Stratmann, 1967; Clapham, 1951, p. 253 ff.; Deissinger, 1992, p. 69 ff.; Deissinger, 1994b.

[2] While in 1968236,000 apprentices had embarked on initial training in manufacturing industry, in 1987 this figure had dropped to far less than 100,000 (See Hough, 1987, p. 105).

[3] This can also be said of the most recent reform stage, i.e. the implementation of National Vocational Qualifications, which raises doubts about whether this really is what protagonists claim it was to be, namely a 'training revolution' (See Callender, 1992; Deissinger, 1994a).

[4] The 1991 White Paper on 'Education and Training in the 21st Century' came out very strongly against the idea of compulsion in vocational education: 'The commitment of young people and their employers to training needs to be secured by voluntary means. Compulsion on employers or young people is unnecessary. [...] Our voluntary approach of offering incentives to young people to train through credits will raise skill levels without the damaging consequences of compulsion' (quoted in: Twining, 1993, p. 77).

[5] For a concise yet informative survey see Greinert, 1994.

[6] The law differs from Land to Land in detail. For Baden-Württemberg see Elser \& Kramer, 1987, pp. 50-53.

[7] For statistical details see Bundesministerium für Bildung, Wissenschaft, Forschung und Technologie, 1995, pp. 3, 20, $53 \mathrm{ff}$.

[8] See Bildungsbrief der Verlagsgruppe Deutscher Wirtschafftsdienst, No. 1/1996, p. 1; Wirtschaft und Berufs-Erziehung, No. 1/1996, p. 4.

[9] In February 1996 unemployment in Germany had risen to 4,270,426. The unemployment rate is now at $11.1 \%$, whereas youth unemployment (under 20 years of age) rates at $8.9 \%$ (See Bundesanstalt für Arbeit, 1996).

[10] All quotations from Federal Ministry of Education and Science, 1994.

[11] See Sections 20; 30; 70 of the Grundgesetz (Basic Law) of the Federal Republic of Germany.

[12] See Sections 36 and 44 VTA respectively: 'The competent body shall establish boards of examiners to be responsible for setting final examinations. (...)'. 'In the absence of other provisions the competent body shall arrange for the provision of initial training within the framework of this Act'. The tasks taken over by the chambers also include the appointment of training counsellors, the qualifying and examining of trainers, the approval of the prolongation or reduction of the training period, the keeping of the register of indentures and the settling of conflicts between training companies and apprentices (Greinert, 1994, p. $87 \mathrm{ff}$.).

[13] See e.g. Sections 1 V; 2 I; 6 I, No. 4; 7; 9, No. 2; 35 VTA.

[14] In Germany, due to a decidedly corporatist approach to vocational training and to Kerschensteiner's achievements as regards the compulsory vocational school, industrial training remained linked to the notion of Beruf which can also be seen 
as the crucial trait of the German pattern of work organisation. The meaning of the term Beruf extends to more than just a trade or occupation in the narrow sense. It also means vocation or profession and has been linked to the notion of somebody's calling into a specific employment. Historically, its connotations embrace both social (the idea of Stand, i.e. station in society) and individual aspects (the idea of having a vocation to which the individual feels inclined). See Zabeck, 1983.

\section{REFERENCES}

ABEL, H. (1963) Von der Fortbildungsschule zur Berufsschule-die Lehrplandiskussion der neunziger Jahre, Die Deutsche Berufs- und Fachschule, 59, pp. 91-100.

ARNOLD, R. \& HÚLSHOFF, T. (Eds) (1981) Rekrutierung und Qualifikation des betrieblichen Bildungspersonals (Heidelberg, Esprint-Verlag).

BeCK, U., Brater, M. \& Daheim, H. (1980) Soziologie der Arbeit und der Berufe. Grundlagen, Problemfelder, Forschungsergebnisse (Reinbek bei Hamburg, Rowohlt).

BENNER, H. (1977) Der Ausbildungsberuf als berufspädagogisches und bildungsökonomisches_Problem (Hannover, Schroedel).

BENNER, H. (1987) Arbeiten zur Ordnung der Berufsausbildung vom DATSch bis zum BiBB, in: W.-D. GREINERT et al. (Eds) Berufsausbildung und Industrie. Zur Herausbildung industrietypischer Lehrlingsausbildung (Berlin, Bundesinstitut für Berufsbildung), pp. 269-293.

BENNER, H. (1994) Zur Neuordnung der Ausbildungsberufe im Berufsfeld Wirtschaft und Verwaltung, in: A. KELL \& H. SCHANZ (Eds) Computer und Berufsbildung. Beiträge zur Didaktik neuer Informations- und Kommunikationstechniken in der kaufmännischen Berufsbildung (Stuttgart, Holland \& Josenhans), pp. 58-75.

Blankertz, H. (1982) Die Geschichte der Pädagogik: von der Aufklärung bis zur Gegenwart (Wetzlar, Büchse der Pandora).

Brown, A. \& Evans, K. (1994) Changing the training culture: lessons from Anglo-German comparisons of vocational education and training, British fournal of Education and Work, 7, pp. 5-15.

BUCHTEMANN, C., Schupp, J. \& SolofF, D.J. (1993) Übergänge von der Schule in den Beruf-Deutschland und USA im Vergleich, Mitteilungen aus der Arbeitsmarkt und Berufsforschung, 26, pp. 507-520.

Bundesanstalt FUR ARBeIT (1996) Pressinformation, 12 (6 March).

Bundesministerium FUR BILDUNG, Wissenschaft, Forschung Und TechNologie (1995) Berufsbildungsbericht 1995 (Bad Honnef, K.H. Bock).

CALIENDER, C. (1992) Will NVQs Work? Evidence from the Construction Industry (IMS Report, No. 228) (Brighton, Institute of Manpower Studies).

CASEY, B. (1986) The Dual Apprenticeship System and the recruitment and retention of young persons in West Germany, British fournal of Industrial Relations, 24, pp. 63-81.

CHILD, J. et al. (1983) A price to pay? Professionalism and work organization in Britain and West Germany, Sociology, 17, pp. 63-78.

Clapham, J. (1951) A Concise Economic History of Britain. From the Earliest Times to 1750, 2nd impression (Cambridge, Cambridge UP).

Clement, W. (1985) Is the Dual System responsible for low youth unemployment in the Federal Republic of Germany?, European fournal of Education, 20, pp. 203 219. 
Degen, U., WALDEN, G. \& Berger, K. (Eds) (1995) Berufsausbildung in den neuen Bundesländern-Daten, Analysen, Perspektiven (Bielefeld, Bertelsmann).

DeIssINGER, TH. (1992) Die englische Berufserziehung im Zeitalter der Industriellen Revolution. Ein Beitrag zur Vergleichenden Erziehungswissenschaft (Würzburg, Königshausen \& Neumann).

DeIssinger, TH. (1994a) Das Reformkonzept der Nationalen beruflichen Qualifikationen'. Eine Annäherung der englischen Berufsbildungspolitik an das 'Berufsprinzip'?, Bildung und Erziehung, 47, pp. 305-328.

Deissinger, TH. (1994b) The evolution of the modern vocational training systems in England and Germany: a comparative view, Compare, 24, pp. 17-36.

DERRY, T.K. (1931/32) The repeal of the apprenticeship clauses of the Statute of Apprentices, Economic History Review, 3, pp. 67-87.

DEUTSCHER AUSSCHUSS FÚR DAS ERZIEHUNGS- UND BILDUNGSWESEN (1966) Gesamtausgabe der Empfehlungen und Gutachten (Stuttgart, Klett).

ElSER, W. \& KRAMER, O. (1987) Grundriss des Schulrechts in Baden-Württemberg (Neuwied, Luchterhand).

EyermanN, E., Fröler, L. \& Honig, G. (1973) Handwerksordnung-Kommentar (München, C.H. Beck).

FEDERAL MINISTRY OF EduCATION AND SCIENCE (Ed.) (1994) Vocational Training Act/Vocational Training Promotion Act (Bonn, Bundesministerium für Bildung und Wissenschaft).

GeISSLER, K.A. (1991) Das Duale System der industriellen Berufsausbildung hat keine Zukunft, Leviathan, 19, pp. 68-77.

GOODHART, D. (1994) The Reshaping of the German Social Market (London, Institute for Public Policy Research).

GreInerT, W.-D. (1994) The 'German System' of Vocational Training. History, Organization, Prospects (Baden-Baden, Nomos).

HARNEY, K. (1985) Der Beruf als Umwelt des Betriebs. Vergleichende, historische und systematische Aspekte einer Differenz, in: VERBÃNDE DER LEHRER AN BERUFLICHEN SCHULEN IN NORDRHEIN-WESTFALEN (Eds) Die Relevanz neuer Technologien für die Berufsausbildung (Krefeld), pp. 118-130.

HEILANDT, A. (1980) Berufsabgrenzung in Metallindustrie, Schiffbau und Chemischer Industrie (1926), in: G. PÄTZOLD (Ed.) Quellen und Dokumente zur betrieblichen Berufsbildung, 1918-1945 (Köln, Böhlau), pp. 134-142.

Higginson, J.H. (1990) Michael Sadler and the German connection, Oxford Review of Education, 16, pp. 245-253.

HILL, P. (1995) The development of a chemical sector modern apprenticeship in process operations and engineering, Education and Training, 37/8, pp. 21-25.

Hough, J.R. (1987) Education and the National Economy (London, Croom Helm).

KIESEWETTER, H. (1989) Industrielle Revolution in Deutschland, 1815-1914 (Frankfurt a.M., Suhrkamp).

Kummel, K. (1980) Zur schulischen Berufserziehung im Nationalsozialismus, in: M. HeInemann (Ed.) Erziehung und Schulung im Dritten Reich, Teil 1: Kindergarten, Schule, Fugend, Berufserziehung (Stuttgart, Klett-Cotta), pp. 275-288.

KUMMERLEIN, S. (1996) Trendumkehr eingeleitet-Ausbildungsplatzsituation '95 und Perspektiven '96, Wirtschaft und Berufs-Erziehung, 48, pp. 104-112.

LuTz, B. (1991) Herausforderungen an eine zukunftsorientierte Berufsbildungspolitik, in: BUNDESINSTTTUT FUR BERUFSBILDUNG (Ed.) Die Rolle der beruflichen Bildung 
und Berufsbildungsforschung im internationalen Vergleich (Berlin, Bundesinstitut für Berufsbildung), pp. 27-36.

LuTz, B. (1994) The difficult rediscovery of 'Professionalism' in: ORganisation FOR Economic Co-operation and Development (Ed.) Apprenticeship: Which Way Forward? (Paris, OECD), pp. 19-28.

Maurice, M., Seluier, F. \& Sillestre, J.-J. (1979) Die Entwicklung der Hierarchie im Industrieunternehmen: Untersuchung eines gesellschaftlichen Effektes, Soziale Welt, 30, pp. 295-327.

Mólges, U. (1967) Bildung und Berufsbildung. Die theoretische Grundlegung des Berufserziehungsproblems durch Kerschensteiner, Spranger, Fischer und Litt (Ratingen, A. Henn).

MÜNCH, J. (1969) Das Berufsbildungsgesetz in historischer und berufspädagogischer Sicht, Die Deutsche Berufs- und Fachschule, 65, pp. 809-825.

MớNCH, J. (1992) Duales System-ein Exportartikel?, in: H. PUTZ (Ed.) Innovationen in der beruflichen Bildung. Hermann Schmidt zum 60. Geburtstag (Berlin, Bundesinstitut für Berufsbildung), pp. 415-425.

MONCH, J. (1994) Das Berufsbildungssystem in der Bundesrepublik Deutschland, hrsg. v. Europäischen Zentrum für die Förderung der Berufsbildung (Luxemburg, Amt für amtliche Veröffentlichungen der Europäischen Gemeinschaften).

MurH, W. (1985) Die historische Entwicklung der Lehrabschlußprüfungen bei den Industrie- und Handelskammern, Wirtschaft und Berufs-Erziehung, 37, pp. 328-336.

PAGE, G.T. (1967) The Industrial Training Act and after (London, Andre Deutsch).

PÃtzolD, G. (Ed.) (1992) Handlungsorientierung in der beruflichen Bildung (Frankfurt a.M., Gesellschaft zur Förderung arbeitsorientierter Forschung und Bildung).

RAGGATT, P. (1988) Quality control in the dual system of West Germany, Oxford Review of Education, 14, pp. 163-186.

ReINISCH, H. (1995) Modernisierung des Lehrens und Lernens in der Berufsschule als berufsbildungspolitisches, theoretisches und didaktisches Problem, in: G. PATzOLD \& G. WALDEN (Eds) Lernorte im dualen System der Berufsbildung (Bielefeld, Bertelsmann), pp. 291-318.

SCHELTEN, A. (1991) Einführung in die Berufspädagogik (Stuttgart, Franz Steiner).

SCHLOTER, A. \& STRATMANN, K. (Eds) (1985) Quellen und Dokumente zur betrieblichen Berufsbildung, 1869-1918 (Köln, Böhlau).

SCHOBER, K. (1994) Krise des dualen Systems? Berufliche Bildung im Spannungsfeld von Demographie, Bildungsverhalten und Beschäftigungsperspektive, in: ForschungsinstTTUT DER FrIEdRICH-EBERT-STIFTUNG (Ed.) Das duale System der Berufsausbildung in der Sackgasse? Modernisierungsdruck und Reformbedarf (Bonn, Friedrich-Ebert-Stiftung), pp. 7-37.

Schober, K. \& Tessarnng, M. (1993) Eine unendliche Geschichte. Vom Wandel im Bildungs- und Berufswahlverhalten fugendlicher (Nürnberg, Bundesanstalt für Arbeit).

SCHONGEN, K., UlRich, J.G. \& WesthoFF, G. (1994) Qualität und Nutzen einer Berufsausbildung im dualen System aus der Sicht von Ausbildungsabsolventen der neunziger Jahre, in: BUNDESINSTTTUT FUR BERUFSBILDUNG (Ed.) Perspektiven der dualen Berufsausbildung (Bielefeld, Bertelsmann), pp. 93-110.

SCHUTTE, F. (1992) Berufserziehung zwischen Revolution und Nationalsozialismus. Ein Beitrag zur Bildungs- und Sozialgeschichte der Weimarer Republik (Weinheim, Deutscher Studien Verlag). 
SCHWICHTENBERG, U. (1991) Qualifizierung für die Ausbildertätigkeit. Eine kritische Betrachtung der Vorbereitungskurse für die Prüfung nach der Ausbildereignungsverordnung, in: M. FRACKMANN (Ed.) Qualifizierungsbedarf und Weiterbildungsangebote für betriebliches Ausbildungspersonal (Alsbach, Leuchtturm), pp. 25-40.

Simons, D. (1966) Georg Kerschensteiner. His Thought and its Relevance Today (London, Methuen).

StratmanN, K. (1967) Die Krise der Berufserziehung im 18. Fahrhundert als Ursprungsfeld pädagogischen Denkens (Ratingen, A. Henn).

StratmanN, K. (1979) Berufs- und Wirtschaftspädagogik, in: H.-H. Groothoff (Ed.) Erziehungswissenschaftiches Handbuch, Bd. V, Teil 2. Die Handlungs- und Forschungsfelder der Pädagogik (Differentielle Pädagogik) (Königstein/Ts., Athenäum), pp. 285-337.

StratmanN, K. (1982) Geschichte der beruflichen Bildung. Ihre Theorie und Legitimation seit Beginn der Industrialisierung, in: H. BLANKERTZ (Ed.) Enzyklopädie Erziehungswissenschaft, Bd. 9.1. Sekundarstufe II-7ugendbildung zwischen Schule und Beruf (Stuttgart, Klett-Cotta), pp. 173-202.

StratMAnN, K. (1991) Betriebliche Berufsausbildung, in: C. BeRg (Ed.) Handbuch der deutschen Bildungsgeschichte, Bd. IV: 1870-1918. Von der Reichsgründung bis zum Ende des Ersten Weltkriegs (München, C.H. Beck), pp. 371-380.

Stratmann, K. \& PǍtzold, G. (1984) Institutionalisierung der Berufsbildung, in: M. BAETHGE \& K. NEVERMANN (Eds) Enzyklopädie Erziehungswissenschaft, Bd. 5: Organisation, Recht und Okonomie des Bildungswesens (Stuttgart, Klett-Cotta), pp. 114-134.

Stratmann, K. \& Schlosser, M. (1990) Das Duale System der Berufsbildung. Eine historische Analyse seiner Reformdebatten (Frankfurt a.M., Gesellschaft zur Förderung arbeitsorientierter Forschung und Bildung).

STRATMANN, K. \& SCHLOTER, A. (Eds) (1982) Quellen und Dokumente zur Berufsbildung, 1794-1869 (Köln, Böhlau).

TimmermanN, D. (1994) Die Rückentwicklung der Arbeitsmarktchancen und -risiken von Fachkräften: Rückblick und Ausblick, in: S. LIESERING, K. SCHOBER \& M. Tessaring (Eds) Die Zukunft der dualen Berufsausbildung. Eine Fachtagung der Bundesanstalt für Arbeit (Nürnberg, Bundesanstalt für Arbeit), pp. 81-109.

TwINING, J. (1993) Vocational Education and Training in the United Kingdom, edited by the European Centre for the Development of Vocational Training (Luxembourg, Office for Official Publications of the European Communities).

WEBER, R. (1985) Berufsbildungsgesetz und Berufsbildungsförderungsgesetz (Bergisch-Gladbach, Heider).

WINKLER, H.A. (1976) From social protectionism to national socialism: the German small-business movement in comparative perspective, fournal of Modern History, 48, pp. 1-18.

ZABECK, J. (1975) Die Bedeutung des Selbstverwaltungsprinzips für die Effizienz der betrieblichen Ausbildung. Untersuchung im Auftrage des Ministers für Wirtschaft, Mittelstand und Verkehr des Landes Nordrhein-Westfalen (Mannheim).

ZABECK, J. (1979) Bildungs- und Beschäftigungswesen, in: BUNDESANSTALT FUR ARBEIT (Ed.) Handbuch zur Berufswahlvorbereitung (Nürnberg, Bundesanstalt für Arbeit), pp. 225-232.

ZABECK, J. (1983) Berufspädagogische Aspekte einer Sozialgeschichte des Berufs, in: L. BeINKE (Ed.) Zwischen Schule und Berufsbildung (München, Lexika Verlag), pp. $27-46$. 
ZABECK, J. (1985) Berufliche Bildung, in: Staatslexikon, hrsg. v. d. Görres-Gesellschaft, Bd. 1 (Freiburg, Herder), pp. 669-683.

ZABECK, J. (1995) Hat das duale System noch eine Zukunft?, in: DIE BERUFLICHEN SCHULEN DER HANSESTADT LOBECK (Eds) 200 fahre Berufsbildende Schulen der Hansestadt Lübeck (Lübeck), pp. 97-101.

Correspondence: Dr Thomas Deissinger, University of Mannheim, Lehrstuhl Erziehungswissenschaft I, Schloss, D-68131 Mannheim, Germany. 